\title{
KEDUDUKAN DAN FUNGSI PERJANJIAN KERJA BERSAMA DALAM PELAKSANAAN HUBUNGAN INDUSTRIAL BERDASARKAN UNDANG-UNDANG NOMOR 13 TAHUN 2003
}

\author{
Oleh : \\ Ardison Asri, S.H, M.H. \\ Dosen Tetap Fakultas Hukum Universitas Dirgantara Marsekal Suryadarma \\ (Email: ardison.mh@gmail.com)
}

\begin{abstract}
Abstrak :
Perjanjian Kerja Bersama sebagai salah satu sarana dalam pelaksanaan hubungan industrial sebagaimana diatur dalam Undang-Undang Nomor 13 Tahun 2003 tentang Ketenagakerjaan. Hal inilah yang menjadi dasar permasalahan dalam penelitian ini, yaitu: (1) bagaimana kedudukan Perjanjian Kerja Bersama dalam pelaksanaan hubungan industrial?; dan (2) apa fungsi Perjanjian Kerja Bersama dalam pelaksanaan hubungan industrial?. Penelitian ini menggunakan metode penelitian hukum normatif yang kemudian dianalisis secara deskriptif kualitatif. Hasil penelitian ini menyimpulkan, (1) kedudukan Perjanjian Kerja Bersama adalah sebagai komponen penting dalam pelaksanaan hubungan industrial; dan (2) Perjanjian Kerja Bersama berfungsi sebagai suatu perjanjian antara pengusaha, serikat pekerja/buruh dan pekerja/buruh, maka para pihak dalam hubungan industrial wajib melaksanakan isi Perjanjian Kerja Bersama.
\end{abstract}

Kata Kunci : Perjanjian Kerja Bersama, kedudukan, fungsi, hubungan industrial.

\section{PENDAHULUAN}

\section{A. Latar Belakang Masalahan}

Undang-Undang Nomor 13 Tahun 2003 tentang Ketenagakerjaan Pasal 1 angka 16 disebutkan bahwa hubungan industrial adalah suatu sistem hubungan yang terbentuk antara para pelaku dalam proses produksi barang dan/atau jasa yang terdiri dari unsur pengusaha, pekerja / buruh, dan pemerintah yang didasarkan pada nilai-nilai Pancasila dan Undang-Undang Dasar Negara Republik Indonesia Tahun 1945. Artinya, dalam hubungan industrial tersebut ada 3 (tiga) unsur yang masing-masing mempunyai fungsi dan tugasnya masing-masing. Fungsi pemerintah sebagaimana disebutkan dalam Pasal 102 ayat (1) UndangUndang Nomor 13 Tahun 2003 
adalah menetapkan kebijakan, memberikan pelayanan, melaksanakan pengawasan, dan melakukan penindakan terhadap pelanggaran peraturan perundangundangan ketenagakerjaan. Sementara fungsi pekerja/buruh dan serikat pekerja/serikat buruh sebagaimana disebutkan dalam Pasal 102 ayat (2) Undang-Undang Nomor 13 Tahun 2003 adalah menjalankan pekerjaan sesuai dengan kewajibannya, menjaga ketertiban demi kelangsungan produksi, menyalurkan aspirasi secara demokratis, mengembangkan keterampilan, dan keahliannya serta ikut memajukan perusahaan dan memperjuangkan kesejahteraan anggota beserta keluarganya. Sedangkan fungsi pengusaha dan organisasi pengusaha sebagaimana disebutkan dalam Pasal 102 ayat (3) Undang-Undang Nomor 13 Tahun 2003 adalah menciptakan kemitraan, mengembangkan usaha, memperluas lapangan kerja, dan memberikan kesejahteraan pekerja/buruh secara terbuka, demokratis, dan berkeadilan.

Dari ketiga unsur dalam hubungan industrial tersebut, yang terlibat langsung dalam proses produksi adalah pengusaha dan pekerja. Hubungan antara pengusaha dan pekerja inilah dalam Pasal 1 angka 15 Undang-Undang Nomor 13 Tahun 2003 disebut hubungan kerja. Oleh karena itu pengusaha dan pekerja terlibat dalam suatu hubungan kerja yang menimbulkan hak dan kewajiban.

Seperti diketahui, tidak semua hak dan kewajiban yang ada dalam hubungan kerja diatur secara rinci oleh ketentuan peraturan perundang- undangan. Undang-undang dibidang ketenagakerjaan, hanya mengatur ketentuan hubungan kerja secara umum. Oleh karena itu perlu pengaturan pelaksanaan hak dan kewajiban para pihak secara rinci yang dituangkan dalam Perjanjian Kerja Bersama.

Sebagai salah satu pilar penting dalam hubungan industrial, maka keberadaan Perjanjian Kerja Bersama sangat penting bagi para pelaku proses produksi barang dan jasa guna mendorong terciptanya hubungan industrial yang harmonis, dinamis dan berkeadilan.

Berdasarkan uraian tersebut di atas dan pengalaman penulis di Industrial Relations (IR) menjadi hal yang menarik untuk membahas mengenai Kedudukan Hukum dan Fungsi Perjanjian Kerja Bersama dalam Hubungan Industrial.

\section{B. Perumusan Masalah}

Sebagai salah satu sarana dalam pelaksanaan hubungan industrial di perusahaan sebagaimana diatur dalam Pasal 103 Undang-Undang Nomor 13 Tahun 2003, maka yang menjadi pokok permasalahan dalam penulisan ini adalah :

1. Bagaimana kedudukan Perjanjian Kerja Bersama dalam pelaksanaan hubungan industrial?

2. Apa fungsi Perjanjian Kerja Bersama dalam pelaksanaan hubungan industrial?

\section{Tujuan Penulisan}

Berdasarkan dari pokok permasalahan tersebut di atas, maka tujuan penulisan ini adalah : 
1. Untuk mengetahui bagaimana kedudukan Perjanjian Kerja Bersama dalam pelaksanaan hubungan industrial.

2. Untuk mengetahui fungsi Perjanjian Kerja Bersama dalam pelaksanaan hubungan industrial.

\section{Metode Penelitian}

\begin{abstract}
Dalam penulisan ini penulis melakukan penelitian dengan menggunakan metode penelitian hukum normatif atau penelitian hukum kepustakaan, yaitu penelitian yang terutama menggunakan bahan kepustakaan atau data sekunder ${ }^{1}$. Menurut Soetandyo Wignjosoebroto, penelitian hukum normatif adalah khusus untuk meneliti hukum sebagai norma positif, as it is written in the books atau yang lebih tepat disebut sebagai penelitian doktrinal ${ }^{2}$. Penelitian doktrinal bertolak dari postulatpostulat normatif yang disebut dengan norma hukum positif dan doktrindoktrin ${ }^{3}$.
\end{abstract}

Jenis data yang digunakan dalam penelitian ini, adalah data sekunder, yaitu dengan menggunakan bahan hukum primer dan bahan hukum sekunder yang dikumpulkan melalui

1 Soerjono Soekanto dan Sri Mamudji, Penelitian Hukum Normatif, Cetakan Ketujuh, PT Raja Grafindo Persada, Jakarta, 2003, hlm. 13.

2 Soetandyo Wignjosoebroto, Hukum, Paradigma, Metode, dan Dinamika Masalahnya, Jakarta: Lembaga Studi dan Advokasi Masyarakat (ELSAM) dan perkumpulan untuk Pembaruan Hukum Berbasis Masyarakat dan Ekologi (HuMa), 2002, hlm. 147. Menurut Soetandyo, di Indonesia, metode doktrinal ini terlanjur secara lazim disebut sebagai metode penelitian yang normatif, untuk melawankan dengan metode penelitian empiris (yang di dalam literatur internasional disebut penelitian nondoktrinal).

${ }^{3}$ Bambang Sunggono, Metodologi Penelitian Hukum (Suatu Pengantar), PT Raja Grafindo Persada, Jakarta, 1997, hlm. 92. studi kepustakaan. Dalam penelitian ini, bahan hukum primer yang digunakan adalah Undang-Undang Nomor 13 Tahun 2003 tentang Ketenagakerjaan. Sedangkan bahan hukum sekunder berupa literaturliteratur yang terkait dengan objek yang diteliti. Bahan hukum yang diperoleh melalui studi pustaka kemudian dianalisis secara deskriptif kualitatif

\section{HASIL PENELITIAN DAN PEMBAHASAN}

\section{A. Kedudukan Perjanjian Kerja Bersama Dalam Pelaksanaan Hubungan Industrial}

\section{Perjanjian Kerja Bersama}

Perjanjian Kerja Bersama sebagai landasan aturan hukum ketengakerjaan yang berlaku pada tingkatan unit kerja perusahaan. Perjanjian Kerja Bersama, yang dalam bahasa Inggris dikenal dengan istilah Collective Labour Agreement (CLA), atau dalam bahasa Belanda disebut dengan istilah Collective Arbeids Overenkomst (CAO), telah dikenal dalam khasanah hukum Indonesia berdasarkan ketentuan dalam Kitab Undang-undang Hukum Perdata (KUHPerdata $)^{4}$. Dalam KUHPerdata Pasal 1601n disebutkan bahwa, "Perjanjian Perburuhan adalah peraturan yang dibuat oleh seorang atau beberapa orang perkumpulan majikan yang berbadan hukum, dan atau

${ }^{4}$ Lalu Husni, Pengantar Hukum Ketenagakerjaan di Indonesia. PT Raja Grafindo Persada, Jakarta, 2003, hlm. 50 
beberapa serikat buruh berbadan hukum, mengenai syarat-syarat kerja yang harus diindahkan pada waktu membuat perjanjian kerja" ${ }^{5}$.

Perjanjian Kerja Bersama dalam dunia ketenagakerjaan Indonesia, juga telah diatur dan ditegaskan posisinya sebagai salah satu sarana untuk membangun hubungan industrial, seperti yang tercantum di dalam Undang-Undang Nomor 13 Tahun 2003 tentang Ketenagakerjaan, Pasal 103 yang menyebutkan bahwa hubungan industrial dilaksanakan melalui sarana :

1. Serikat pekerja/serikat buruh;

2. Organisasi pengusaha;

3. Lembaga kerja sama bipartit;

4. Lembaga kerja sama tripartit;

5. Peraturan perusahaan;

6. Perjanjian kerja bersama;

7. Peraturan perundang-undangan ketenagakerjaan; dan

8. Lembaga penyelesaian perselisihan hubungan industrial.

Hal tersebut di atas, menjelaskan bahwa untuk membangun hubungan industrial, harus dilandasi oleh seperangkat aturan-aturan sistematis mengenai hak dan kewajiban masing-masing pihak. Salah satu aturan yang diakui oleh peraturan perundangundangan kita adalah Perjanjian Kerja Bersama. Lebih lanjut dalam Undang-Undang Nomor 13 Tahun 2003 tentang Ketenagakerjaan, Pasal 1 angka 21 menyebutkan bahwa, "Perjanjian kerja bersama adalah perjanjian yang merupakan hasil perundingan antara serikat pekerja/serikat buruh atau beberapa serikat pekerja/serikat buruh yang tercatat pada instansi yang bertanggung jawab dibidang ketenagakerjaan dengan pengusaha atau beberapa pengusaha atau perkumpulan pengusaha yang memuat syarat-syarat kerja, hak dan kewajiban kedua belah pihak".

Berdasarkan pengertian Perjanjian Kerja Bersama tersebut di atas, maka rumusan mengenai Perjanjian Kerja Bersama ini dapat dibagi atas beberapa unsur, yaitu sebagai berikut :

1. Perjanjian Kerja Bersama adalah perjanjian; oleh karena itu asas hukum perjanjian harus melekat pada Perjanjian Kerja Bersama;

2. Subjek hukum Perjanjian Kerja Bersama terdiri atas serikat pekerja/buruh dan pengusaha; kemungkinan lainnya adalah gabungan serikat pekerja/buruh dan beberapa atau perkumpulan pengusaha; hal yang ingin ditekankan adalah bahwa pekerja/buruh sebagai individu tidak dapat tampil sebagai subjek hukum di dalam Perjanjian Kerja Bersama;

3. Memuat syarat-syarat kerja, hak dan kewajiban para pihak, yaitu pengusaha dan pekerja/buruh; hal yang ingin ditekankan disini adalah bahwa Perjanjian Kerja Bersama hendak menyediakan pedoman, wujudnya perjanjian ${ }^{6}$, bagi pengusaha dan pekerja

${ }^{5}$ Ibid. ${ }^{6}$ Untuk diketahui, perjanjian merupakan salah satu
sumber hukum formal. 
/buruh; dengan demikian tercipta kepastian hukum. ${ }^{7}$

\section{Blacklaw Dictionary} memberikan pengertian collectivebargaining agreement sebagai " $A$ contract that is made betweent an employer and a labor union and that regulate employment conditions. Also termed collective labor agreement or trade agreement". Rumusan Blacklaw Dictionary ini mirip dengan rumusan Perjanjian Kerja Bersama di dalam Undang-Undang Nomor 13 Tahun 2003. Hal yang ditekankan oleh Blacklaw Dictionary adalah collective agreement merupakan hasil dari collective bargaining negotiation. Hal ini logis karena hal-hal yang tercantum di dalam collective agreement harus merupakan kompromi antara pengusaha dan serikat pekerja/buruh. Blacklaw Dictionary memberikan rumusan collective bargaining negotiation sebagai "negotiation betweent an employer and the representativers of organized employees to determine the conditions of employment, such as wages, hours, and fringe benefits".

Berdasarkan rumusan collective agreement oleh Blacklaw Dictionary tersebut dapat ditegaskan bahwa di negara penganut comman law system pun pekerja/buruh secara individual tidak dapat tampil sebagai subjek hukum di dalam pembuatan collective agreement. Hal

${ }^{7}$ Abdul R. Budiono, Hukum Perburuhan, PT Indeks, Jakarta, 2008, hlm. 106.

${ }^{8}$ Bryan A. Gardner, Blacklaw Dictionary, dikutip oleh Abdul R. Budiono, Hukum Perburuhan, PT Indeks, Jakarta, 2008, hlm. 106.

${ }^{9} \mathrm{Ibid}$. ini menunjukan kekhasan collective agreement atau Perjanjian Kerja Bersama sebagai suatu perjanjian.

Sebagai suatu perjanjian, maka Perjanjian Kerja Bersama tidak terlepas dari ketentuan syarat sahnya suatu perjanjian pada umumnya, yang menurut Pasal 1320 KUHPerdata harus memenuhi syarat-syarat sebagai berikut :

1. Sepakat mereka yang mengikatkan diri.

2. Kecakapan untuk membuat suatu perjanjian.

3. Suatu hal tertentu.

4. Suatu sebab yang halal.

Untuk lebih jelasnya, maka perlu kiranya dijelaskan keempat syarat di atas. Uraian penjelasan syarat-syarat tersebut sebagai berikut :

1. Sepakat mereka yang mengikatkan diri Maksudnya antara para pihak tersebut haruslah seiya sekata terhadap apa yang diperjanjikan. Apabila ada paksaan atau dwang, kekhilafan atau dwaling, dan penipuan atau bedrog, maka berarti tidak ada perjanjian. Pasal $1321 \quad$ KUHPerdata menyatakan : "Tiada sepakat yang sah apabila sepakat itu diberikan karena kekhilafan atau diperolehnya dengan paksaan atau penipuan". Arti paksaan itu sendiri telah ditegaskan dalam Pasal 1323, 1324 dan 1325 KUHPerdata, dan dapat dirinci sebagai berikut: 
a. Paksaan yang dilakukan terhadap orang yang membuat suatu perjanjian, merupakan alasan untuk batalnya perjanjian, juga bila paksaan itu dilakukan oleh pihak ketiga untuk kepentingan pihak tertentu.

b. Paksaan telah terjadi, bila perbuatan itu menakutkan orang yang berpikiran sehat dan orang yang bersangkutan merasa terancam.

c. Paksaan juga membatalkan perjanjian, apabila paksaan dilakukan terhadap suami atau istri atau anak-anak atau keluarga.

2. Kecakapan Membuat Suatu Perjanjian Persyaratan ini mengaju pada kemampuan atau kecakapan dari pelaku yang dapat membuat perjanjian tersebut, sedangkan yang dapat menjadi pelaku itu ialah pendukung hak dan kewajiban. Jika yang membuat perjanjian adalah suatu badan hukum, maka badan hukum tersebut harus memenuhi syarat-syarat badan hukum yang antara lain sebagai berikut :

a. Adanya harta kekayaan yang terpisah,

b. Mempunyai tujuan tertentu,

c. Mempunyai kepentingan sendiri,

d. Ada organisasi.

Sedangkan jika para pihak yang membuat perjanjian adalah orang, maka orang yang dianggap sebagai subyek hukum yang bisa melakukan hubungan hukum dengan pihak lain, adalah orang-orang yang tidak termasuk dalam pengertian Pasal 1330 KUHPerdata sebagai berikut :

a. Orang-orang yang belum dewasa,

b. Mereka yang ditaruh di bawah pengampuan,

c. Orang perempuan dalam halhal yang ditetapkan oleh undang-undang telah melarang membuat suatu perjanjian-perjanjian tertentu.

Sesuai dengan ketentuan tersebut di atas, maka mereka yang termasuk dalam kriteria tersebut di atas tidak bisa membuat suatu perjanjian, dan sebaliknya jika mereka tidak termasuk dalam ketiga kriteria tersebut di atas, maka mereka mempunyai hak untuk membuat suatu perjanjian.

3. Suatu Hal Tertentu Pengertian suatu hal tertentu ialah bahwa perjanjian itu harus menjadikan objek itu tertentu. Hal ini diatur dalam Pasal 1333 KUHPerdata bahwa barang yang menjadi obyek suatu perjanjian harus ditentukan jenisnya.

4. Suatu Sebab Yang Halal Yang dimaksud disini adalah sebabsebab yang tidak dilarang oleh Undang-undang, tidak bertentangan dengan kesusilaan dan ketertiban umum, ketentuan ini disebutkan pada Pasal 1337 KUHPerdata.

Keempat syarat tersebut bersifat kumulatif, artinya harus dipenuhi semuanya baru dapat 
dikatakan bahwa perjanjian tersebut sah. Syarat sepakat mereka yang mengikatkan diri dan kecakapan untuk membuat suatu perjanjian dalam hukum perdata disebut sebagai syarat subjektif karena menyangkut mengenai orang yang membuat perjanjian, sedangkan syarat suatu hal tertentu dan suatu sebab yang halal disebut sebagai syarat objektif karena menyangkut objek perjanjian $^{10}$.

Bila syarat objektif tidak dipenuhi, maka perjanjian itu batal demi hukum artinya dari semula perjanjian tersebut dianggap tidak pernah ada. Sementara jika yang tidak dipenuhi adalah syarat subjektif, maka akibat hukum dari perjanjian tersebut dapat dibatalkan ${ }^{11}$.

\section{Hubungan Industrial}

Pasal 1 angka 16 UndangUndang Nomor 13 Tahun 2003 menyebutkan bahwa hubungan industrial adalah suatu sistem hubungan yang terbentuk antara para pelaku dalam proses produksi barang dan/atau jasa yang terdiri dari unsur pengusaha, pekerja/buruh, dan pemerintah yang didasarkan pada nilai-nilai Pancasila dan UndangUndang Dasar Negara Republik Indonesia Tahun 1945. Sementara hubungan antara pekerja / buruh dengan

${ }^{10}$ Djumaldi, Hukum Perburuhan dan Perjanjian Kerja, PT Raja Grafindo Persada, Jakarta, 2002, hlm. 1516.

${ }^{11}$ Ibid. pengusaha sebagai pelaku dalam proses produksi barang dan/atau jasa, lahir atau tercipta karena adanya hubungan hukum dalam bentuk hubungan kerja.

Pasal 1 angka 15 Undangundang Nomor 13 Tahun 2003, disebutkan bahwa, "Hubungan kerja adalah hubungan antara pengusaha dengan pekerja berdasarkan perjanjian kerja yang mempunyai unsur pekerjaan, upah, dan perintah". Sementara menurut Zainal Azikin, hubungan kerja dapat diartikan sebagai hubungan antara buruh dan majikan yang terjadi setelah diadakan perjanjian kerja, dimana buruh menyatakan kesanggupannya untuk bekerja pada majikan dengan menerima upah dan majikan menyatakan kesanggupannya untuk mempekerjakan buruh dengan membayar upah ${ }^{12}$.

Dari pengertian di atas, maka sangat jelaslah bahwa hubungan kerja sebagai bentuk hubungan hukum, lahir atau tercipta setelah adanya "perjanjian kerja" antara pengusaha dengan pekerja / buruh. Sedangkan perjanjian kerja, didefinisikan oleh Abdul Rachman Budiono sebagai hubungan kerja yang terjadi setelah diadakan perjanjian kerja antara pekerja dan majikan, dimana pekerja menyatakan kesanggupannya untuk bekerja kepada majikan dengan menerima upah, dan pada sisi yang lain, majikan menyatakan

${ }^{12}$ Zainal Azikin, Dasar-Dasar Hukum Perburuhan, PT. Raja Grafindo Persada, Jakarta, 2004, hlm. 35. 
kesanggupannya untuk mempekerjakan pekerja dengan membayar upah atau imbalan lainnya ${ }^{13}$.

Sementara itu menurut Suharnoko, perjanjian kerja merupakan suatu ikatan kerja yang secara prinsip dibuat antara pihak-pihak atau unsur-unsur yang ada dalam hubungan industrial, yakni antara pihak pengusaha sebagai orang yang memberi kerja, dan pihak pekerja sebagai orang yang dipekerjakan ${ }^{14}$. Selain itu, pengertian mengenai perjanjian kerja juga dikemukakan oleh Iman Soepomo yang mengemukakan bahwa, "perjanjian kerja adalah suatu perjanjian dimana pihak kesatu, buruh, mengikatkan diri untuk bekerja dengan menerima upah pada pihak lainnya, majikan, yang mengikatkan diri untuk mengerjakan buruh itu dengan membayar upah". ${ }^{15}$

Selanjutnya perihal pengertian perjanjian kerja, juga ditanggapi oleh Subekti yang menyatakan bahwa, "perjanjian kerja merupakan perjanjian antara seorang "buruh" dengan seorang "majikan", perjanjian mana ditandai oleh ciri-ciri : adanya satu upah gaji tertentu yang diperjanjikan dan adanya suatu

13 Abdul Rachman Budiono, Hukum Perburuhan di Indonesi, PT Raja Grafindo Persada, Jakarta, 1995, hlm. 56.

${ }^{14}$ Suharnoko, Hukum Perjanjian Teori dan Analisis Kasus, Prenada Media, Jakarta, 2004, hlm. 67.

15 Imam Soepomo, Pengantar Hukum Perburuhan, Djambatan, Jakarta, 1987, hlm. 57. hubungan di peratas (bahasa belanda dierstverhanding) yaitu suatu hubungan berdasarkan mana pihak yang satu (majikan) berhak memberi perintahperintah yang harus ditaati oleh pihak yang lain-lain". ${ }^{16}$

Senada dengan pengertian perjanjian kerja di atas, Pasal 1 angka $14 \quad$ Undang-Undang Nomor 13 Tahun 2003 menyebutkan, bahwa "Perjanjian kerja adalah perjanjian antara pekerja/buruh dengan pengusaha atau pemberi kerja yang memuat syarat-syarat kerja, hak dan kewajiban para pihak".

Dari pengertian di atas, maka sangat jelaslah bahwa hubungan kerja sebagai bentuk hubungan hukum, lahir atau tercipta setelah adanya "Perjanjian Kerja" antara pengusaha dengan pekerja / buruh. Adapun substansi perjanjian kerja yang dibuat, tidak boleh bertentangan dengan peraturan ketenagakerjaan yang berlaku dalam hal ini Perjanjian Kerja Bersama. Dengan demikian kedudukan hukum Perjanjian Kerja Bersama sebagai komponen dalam hubungan industrial.

\section{B. Fungsi Perjanjian Kerja Bersama Dalam Pelaksanaan Hubungan Industrial}

Pasal $1313 \quad$ KUHPerdata, menjelaskan bahwa "suatu perjanjian adalah suatu perbuatan dengan mana satu orang atau lebih mengikatkan dirinya terhadap satu orang lain atau

${ }^{16}$ R. Subekti, Aneka Perjanjian, Alumni, Bandung, 1977, hlm. 63 
lebih". Dalam suatu kontrak perjanjian terdapat banyak perikatanperikatan berwujud klausula yang disusun dalam pasal-pasal perjanjian yang berlaku dan mengikat para pihak untuk melaksanakannya. Klausulaklausula tersebut saling berhubungan satu sama lain yang dibangun berdasarkan kebebasan para pihak yang terlibat dalam perjanjian.

Menurut hukum perjanjian, kebebasan kedua pihak dalam melakukan perjanjian, harus terlebih dahulu dicapai melalui suatu proses negosiasi sebelum masuk pada kesepakatan yang mengikat. Lebih lanjut, dalam Pasal 1233 KUHPerdata, dijelaskan bahwa "Perikatan lahir karena persetujuan dan atau karena Undang-undang". Kaidah hukum pasal tersebut di atas ditegaskan bahwa perikatan tersebut lahir sebagai konsekuensi hukum dari apa yang telah diperjanjikan, apa yang diperjanjikan tersebut, dapat dipertegas dalam Pasal 1234 KUHPerdata yang menyatakan bahwa "Perikatan ditujukan untuk memberikan sesuatu, untuk berbuat sesuatu, atau untuk tidak berbuat sesuatu".

Sebagai suatu perjanjian, Perjanjian Kerja Bersama di dalam klausula-klasula yang dituangkan harus merupakan perwujudan perundingan dua pihak, yaitu serikat pekerja/buruh dan pengusaha. Berkaitan dengan hal ini Pasal 116 ayat (2) Undang-Undang Nomor 13 Tahun 2003 menegaskan bahwa penyusunan Perjanjian Kerja Bersama dilaksanakan secara musyawarah.
Formalitas Perjanjian Kerja Bersama sebagaimana diatur dalam Pasal 116 ayat (3) Undang-Undang Nomor 13 Tahun 2003, adalah :

1. Dibuat dalam bentuk tertulis;

2. Ditulis dengan huruf latin;dan

3. Menggunakan bahasa Indonesia.

Ketiga syarat formal tersebut merupakan syarat kumulatif. Artinya tiga syarat tersebut harus terwujud ${ }^{17}$.

Selanjutnya, Perjanjian Kerja Bersama sekurang-kurang memuat :

1. Hak dan kewajiban pengusaha;

2. Hak dan kewajiban serikat pekerja/buruh serta pekerja/buruh;

3. Jangka waktu dan tanggal mulai berlakunya Perjanjian Kerja Bersama; dan

4. Tanda tangan para pihak pembuat Perjanjian Kerja Bersama ${ }^{18}$.

Perjanjian Kerja Bersama yang telah dihasilkan melalui perundingan antara pengusaha dan serikat pekerja/buruh harus didaftarkan kepada instansi yang bertanggung jawab di bidang ketenagakerjaan. Pihak yang dibebani kewajiban untuk mendaftarkan Perjanjian Kerja Bersama tersebut adalah pengusaha.

Jika kelengkapan persyaratan pendaftaran Perjanjian Kerja Bersama telah terpenuhi dan tidak ada materi yang bertentangan dengan peraturan perundang-undangan yang berlaku, maka pejabat yang ditunjuk oleh instansi ketenagakerjaan harus menerbitkan Surat Keputusan Pendaftaran Perjanjian Kerja

\footnotetext{
${ }^{17}$ Abdul Rachmad Budiono, Op.cit, hlm. 107.

${ }^{18}$ Ketentuan tersebut diatur dalam Pasal 124 ayat (1) Undang-Undang Nomor 13 Tahun 2003 Tentang Ketenagakerjaan.
} 
Bersama. Dengan begitu sejak tanggal mulai berlakunya Perjanjian Kerja Bersama pengusaha, serikat pekerja /buruh dan pekerja/buruh wajib melaksanakan isi Perjanjian Kerja Bersama tersebut. Pengusaha dan serikat pekerja / buruh wajib memberitahukan isi dari Perjanjian Kerja Bersama kepada seluruh pekerja /buruh.

Kewajiban untuk melaksanakan isi dari Perjanjian Kerja Bersama tersebut sebagai suatu perjanjian, maka ketentuan itu sebagaimana diatur dalam Pasal 1338 KUHPerdata yang menyebutkan :

1. Semua persetujuan yang dibuat secara sah sesuai dengan Undangundang berlaku sebagai Undangundang bagi mereka yang membuatnya. Artinya bahwa semua ketentuan dalam perjanjian yang telah disepakati para pihak mengikat dan wajib dilaksanakan oleh para pihak yang membuatnya.

2. Persetujuan itu tidak dapat ditarik kembali selain dengan kesepakatan kedua belah pihak atau karena alasan-alasan yang ditentukan oleh Undang - undang. Artinya perjanjian yang telah dibuat dan disepakati berlaku secara timbal balik.

3. Persetujuan harus dlaksanakan dengan itikad baik. Artinya kesepakatan yang telah tertuang dalam perjanjian untuk ditaati oleh kedua belah pihak.

Dengan demikian fungsi Perjanjian Kerja Bersama dalam hubungan industrial bagi para pelaku proses produksi yaitu pengusaha dan serikat pekerja/buruh serta pekerja/buruh adalah sebagai Undang-undang bagi mereka. Dengan begitu sejak tanggal mulai berlakunya Perjanjian Kerja Bersama pengusaha, serikat pekerja /buruh dan pekerja/buruh wajib melaksanakan isi Perjanjian Kerja Bersama tersebut.

\section{PENUTUP}

\section{A. Kesimpulan}

Dari pembahasan tentang kedudukan dan fungsi Perjanjian Kerja Bersama dalam pelaksanaan hubungan industrial dapat ditarik kesimpulan, adalah sebagai berikut :

1. Sebagai salah satu sarana untuk membangun hubungan industrial sebagaimana diatur di dalam Undang-Undang Nomor 13 Tahun 2003 tentang Ketenagakerjaan Pasal 103, maka kedudukan Perjanjian Kerja Bersama adalah sebagai komponen penting dalam pelaksanaan hubungan industrial.

2. Perjanjian Kerja Bersama sebagai suatu perjanjian antara pengusaha, serikat pekerja/buruh dan pekerja /buruh, maka para pihak dalam hubungan industrial wajib melaksanakan isi Perjanjian Kerja Bersama.

\section{B. Saran}

1. Sebagai komponen penting dalam kedudukan hukum pelaksanaan hubungan industrial, maka diperlukan kecakapan bagi kedua belah pihak, baik pihak serikat pekerja/buruh maupun pihak pengusaha. Hal itu harus sudah ada sejak tahapan pembuatan Perjanjian Kerja Bersama, yaitu kemampuan dalam bernegosiasi, pemahaman tentang peraturan di 
bidang ketenagakerjaan, prosedur dan tata cara pembuatan Perjanjian Kerja Bersama serta kemampuan contract draft dan legal draft dalam menyiapkan konsep Perjanjian Kerja Bersama masing-masing pihak. Contract draft dan legal draft ini juga merupakan media untuk membangun kesepahaman antar kedua belah pihak terkait dengan kedudukan hukum dan fungsi Perjanjian Kerja Bersama dalam sistem hukum Indonesia, khususnya hukum perjanjian yang mengikat keduanya.

2. Adanya Perjanjian Kerja Bersama di suatu perusahaan bukanlah sekedar untuk menggugurkan kewajiban atas tuntutan peraturan perundangan-undangan di bidang ketenagakerjaan dan bukan pula sekedar dijadikan relief bangunan candi sebagai hiasan bagi para pekerja/buruh dan pengusaha, tetapi dengan adanya Perjanjian Kerja Bersama tersebut berfungsi dalam hubungan industrial yaitu antara pekerja/buruh dan pengusaha seperti "jangan ada dusta diantara kita". Semoga...!!!

\section{DAFTAR PUSTAKA}

\section{A. Buku-buku}

Azikin, Zainal, 2004, Dasar-Dasar Hukum Perburuhan, PT Raja Grafindo Persada, Jakarta.

Budiono, Abdul Rachman, 1995, Hukum Perburuhan di Indonesia, PT Raja Grafindo Persada, Jakarta.

2008 ,

Hukum Perburuhan, PT Indeks, Jakarta.
Djumaldi, 2002, Hukum Perburuhan dan Perjanjian Kerja, PT Raja Grafindo Persada, Jakarta.

Husni, Lalu, 2003, Pengantar Hukum Ketenagakerjaan di Indonesia, PT Raja Grafindo Persada, Jakarta.

Subekti, R., 1977, Aneka Perjanjian, Alumni, Bandung.

Suharnoko, 2004, Hukum Perjanjian Teori dan Analisis Kasus, Prenada Media, Jakarta.

Sunggono, Bambang, 1997, Metodologi Penelitian Hukum (Suatu Pengantar), PT Raja Grafindo Persada, Jakarta.

Soepomo, Imam, 1985, Pengantar Hukum Perburuhan, Djambatan, Jakarta.

Soekanto, Soerjono dan Sri Mamudji, 2003, Penelitian Hukum Normatif, Cetakan Ketujuh, PT Raja Grafindo Persada, Jakarta.

Rusli, Hardijan, 2003, Hukum Ketenagakerjaan, PT Ghalia Indonesia, Jakarta.

Wignjosoebroto, Soetandyo, 2002, Hukum, Paradigma, Metode, dan Dinamika Masalahnya, Lembaga Studi dan Advokasi Masyarakat (ELSAM) dan Perkumpulan untuk Pembaruan Hukum Berbasis Masyarakat dan Ekologi (HuMa), Jakarta.

\section{B. Peraturan Perundang-undangan}

Kitab Undang-undang Hukum Perdata.

Undang-Undang Nomor 13 Tahun 2003 Tentang Ketenagakerjaan. 